\title{
DEVELOPMENT OF SPECIFIC PRIMERS FOR INTER SPECIES PHYLOGENY RELATIONSHIP ON Crocodilian sp
}

\author{
Herdhanu Jayanto ${ }^{1}$ and Budi Setiadi Daryono ${ }^{2}$ \\ 1) Kelompok Studi Herpetologi, Faculty of Biology, Universitas Gadjah Mada. \\ 2) Genetics Laboratory, Faculty of Biology, Universitas Gadjah Mada, \\ author h.jayanto@gmail.com
}

\begin{abstract}
Poaching, trafficking, and illegal product trading are classic activities which frequently faced by Crocodilian group. To overcome, laws need supporting methods for a decision of these all activities which threaten crocodile species. This will require species identification that associated to taxonomy classification. Crocodilian species are very similar in morphology. This may result to a false identification especially when working on incomplete specimen. Currently, twenty-four existing Crocodilian species are continuously revised to improve the precise placement and/or acceptance of certain species on Crocodilian classification. Herein we address this issue using Cytochrome-b. The idea was to obtain genus specific primer from Cytochrome- $b$ and then tested the precision of the designed primers using bioinformatics tools' Primer-BLAST and CLC sequence Viewer 6 . The designed primers showed a highly specificity on species level. The phylogenetic tree constructed by is relatively precise compared to reported phylogenetic trees. These specific primers together with the genus specific primers may give valuable and important support for the effective and efficient identification of Crocodilian group.
\end{abstract}

Keywords: Crocodilian, illegal trading, Cytochrome-b, specific primer, bioinformatic

\section{INTRODUCTION}

Molecular techniques are considered to be useful tools to answer many biological questions. In which over fifty years they developed, thus majorly become root of bioinformatics in nowadays. Bioinformatics cannot be ignored, it consists million of genetic sequences information database and various valuable analyzing tools (Mount, 2004). We observed mtDNA are popular and widely used in Crocodylian phylogenetic studies, together with their sequences information deposited in GenBank (see McAliley et al., 2006; Li et al., 2007; Meganathan et al., 2010; Meganathan et al., 2011; Meredith et al., 2011).

Poaching, trafficking, illegal product trading are activities which frequently faced by Crocodilian group. To response these problems, laws need a supporting scientific method to penalty these all activities which threaten crocodile species. This required species identification that associated to taxonomy classification. Currently, twenty-four of existing Crocodilian species were continuously revised for the correct placement of species on Crocodilian classification. For instance Tomistoma schlegelii from Crocodylidae had experienced two times revision (Willis et al., 2007; Vitt \& Caldwell, 2009; Uetz \& Hallermann, 2012). As we know Crocodylian species are very similar in morphology. This may lead to identification problems especially when we work on incomplete specimen. Herein we address this issue using Cytochrome-b which has been used for animal identification or forensic diagnosis (Hsies et al., 2001; Prusak et al., 2005; Meganathan et al., 2009). The idea was to obtain a genus specific primer from Cytochrome-b and then tested the precision of the designed primers using bioinformatics tools' Primer-BLAST and CLC sequence Viewer 6 . 


\section{MATERIALS AND METHODS}

The major work of this study were done in silico. The Cytochrome-b sequences of available species were retrieved from GenBank NCBI (http://www.ncbi.nlm.nih.gov/). The phylogenetic tree constructed from alignment of sequences (Table 1.) with CLC sequence Viewer 6 software. Primer-BLAST (Basic Local Alignment Search Tool) software was used to design primers, followed by arrangement to discover the genus specific primers.

Table 1. Sequences from NCBI which used in this study. The Sequences are from Oaks (2011), used with permission.

\begin{tabular}{lc}
\hline \multicolumn{1}{c}{ Species } & Accesion number \\
\hline Crocodylidae & \\
\hline Crocodylus porosus & JF315290 \\
Crocodylus siamensis & JF315292 \\
Crocodylus novaeguineae & JF315289 \\
Crocodylus johsntoni & JF315260 \\
Crocodylus mindorensis & JF315252 \\
Crocodylus palustris & JF315254 \\
Crocodylus niloticus & JF315270 \\
Crocodylus intermedius & JF315246 \\
Crocodylus moreletii & JF315256 \\
Crocodylus acutus & JF315263 \\
Crocodylus rhombifer & JF315255 \\
Crocodylus suchus & - \\
Mecistops cathapractus & JF315280 \\
Osteolaemus tetraspis & JF315272 \\
Tomistoma schlegelii & JF315305 \\
\hline Gavialidae & \\
\hline Gavialis gangeticus & JF315302 \\
\hline Alligatoridae & \\
\hline Alligator mississippiensis & JF315322 \\
Alligator sinensis & JF315321 \\
Caiman crocodilus & JF315307 \\
Caiman yacare & JF315314 \\
Caiman latirostris & JF315308 \\
Paleosuchus palpebrosus & JF315319 \\
Paleosuchus trigonatus & JF315324 \\
Melanosuchus niger & JF315312 \\
\hline & \\
\hline & \\
\hline
\end{tabular}

\section{RESULTS AND DISCUSSION}

Constructed tree showed different of Osteolaemus tetraspis, Mecistops cathrapactus, T. schlegelii and Gavialis gangeticus belonging in outgroup clade. The Neighbor-joining tree showed that every Crocodylus members of the Crocodylidae were monophyletic, while $O$. tetraspis and $M$. cathrapactus were have paraphyletic relationship with Crocodylus genus. The T. schlegelii and G. gangeticus have closest paraphyletic relationship with Alligatoridae. Whereas in UPGMA tree. O. tetraspis, M. cathrapactus, T.schlegelii and G. gangeticus placed paraphyletic with Alligatoridae. Within Alligatoridae, all members of Caimaninae have paraphyletic relationship with Alligatorinae. Without consideration of precision between UPGMA and neighbor-joining tree from Cytochrome- $b$, both trees shows contradiction with McAliley et al. (2006) and Meganathan et al. (2010). They use bayesian analyses, which used Ornithine-decarboxylase and C-mos, also ND4 and ND6 respectively. In their studies O.s tetraspis, M. cathrapactus, T. schlegelii and G. gangeticus are consistently placed within Crocodylidae clade. 


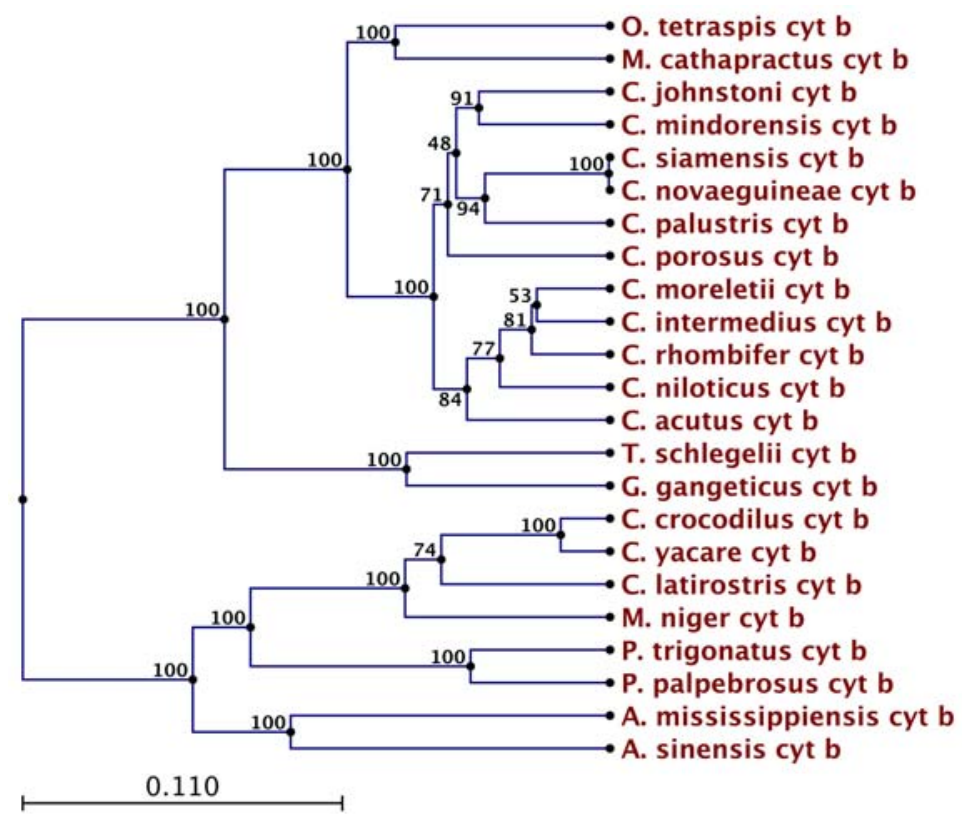

Figure 1. UPGMA tree obtained from Cytochrome-b analyses illustrating the relationship among species.

The primer we designed in this study showed a high specificity on species level. Only two primers for duo among genus of Crocodylus shares same primers (Table 2.). There is none for others eight in genus of Crocodylus. This also happened to in genus Alligator, Caiman and Paleosuchus. However, several Genus only have one member like Mecistops, Osteolaemus, Tomistoma, Gavialis, dan Melanosuchus. Their Species specific primers are consider as Genus specific primers with Cytochrome- $b$.

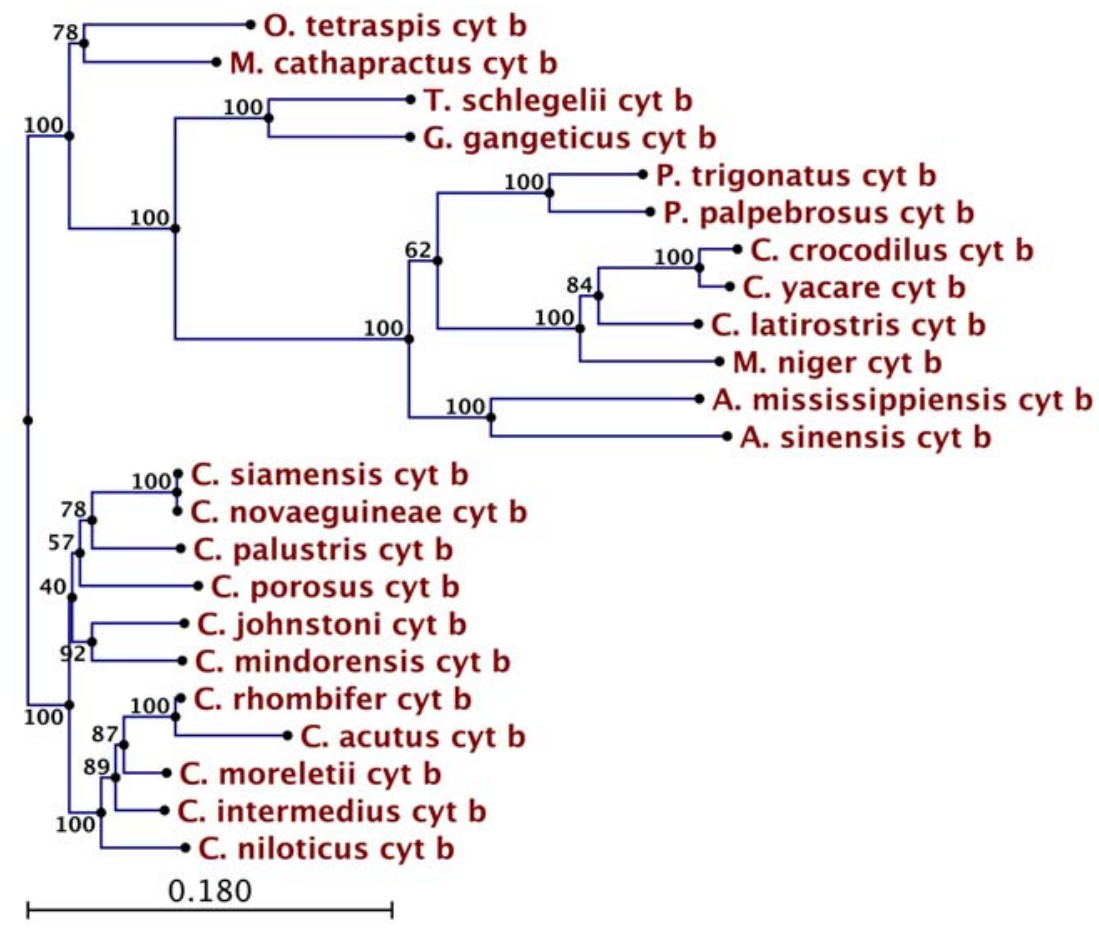

Figure 2. Neighbor-joining tree obtained from Cytochrome- $b$ analyses illustrating the relationship among species. 
Table 2. Results of designed primer from Cytochrome-b.

\begin{tabular}{|c|c|c|c|}
\hline Species & $\begin{array}{c}\text { Forward Primer } \\
\left(5^{\prime} \rightarrow 3^{\prime}\right)\end{array}$ & $\begin{array}{c}\text { Reverse Primer } \\
\left(5^{\prime} \rightarrow 3^{\prime}\right)\end{array}$ & $\begin{array}{c}\text { Product } \\
\text { lenght }\end{array}$ \\
\hline 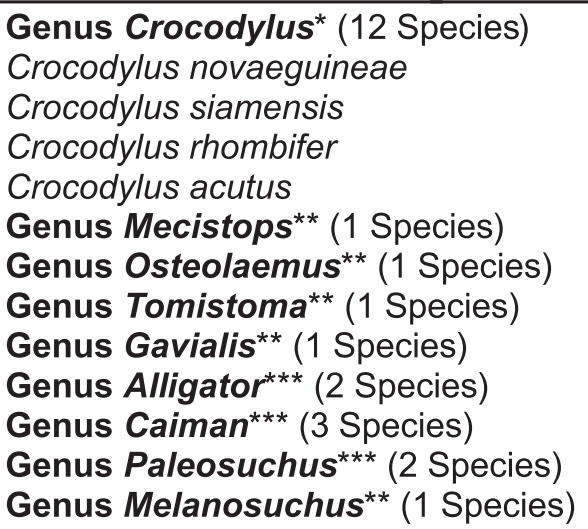 & $\begin{array}{l}\text { 'GCCGCTGTCGT } \\
\text { CACACACCT' } \\
\text { 'GGGCCATCAGT } \\
\text { CAACAGCGCA' }\end{array}$ & $\begin{array}{l}\text { 'GGAGTTGGGA } \\
\text { CGGGGGCGT' } \\
\text { 'TGGGATAGAG } \\
\text { GGCGCAGGCT' }\end{array}$ & $\begin{array}{l}400 \\
467\end{array}$ \\
\hline
\end{tabular}

notes: *) 8 Species only have species specific primers, ${ }^{* *}$ ) Species specific primers are considered Genus specific primers, ${ }^{* \star \star}$ ) no Genus specific primers obtained

Specific primers may very valuable; moreover the genus specific primers are important for effective and efficient identification tools. Unanjak et al. (2011) and Meganathan et al. (2009) used the same principal: nested-PCR. Hence, in their studies, effectiveness of primers were tested in agarose gel. Although they do not accommodate all Crocodilian species and only showing Species specific, the primers already can distinguish DNA template target and showing no cross reaction. Their studies have a promising future for animal forensics and conservations. For this reason, we are still looking suitable loci to develop effective and efficient molecular identification tools.

\section{ACKNOWLEDGMENT}

We are grateful to thank Jamie R. Oaks for his permission to use his sequence deposits.

\section{REFERENCES}

Anonim. 2011. Complete mitochondrial genome sequences of three Crocodylus species and their comparison within the Order Crocodylia. Gene, vol. 478: 35-41.

Hsieh, H., H. Chiang, L. Tsai, S. Lai, N. Huang, A. Linacre, and J. C. Lee. 2001. Cytochrome B Gene for Species Identification of The Conservation Animal. Forensic Science International, vol. 122: 7-8.

Li, Y., X. Wu, X. Ji, P. Yan, and G. Amato. 2011. The Complete Mitochondrial Genome of Saltwater Crocodile (Crocodylus porosus) and Phylogeny of Crocodilians. Journal of Genetics and Genomics, vol. 34(2): 119-128.

McAliley, L. R., R. E. Willis, D. A. Ray, P. S. White, C. A. Brochu, and L. D. Densmore III. 2006. Are Crocodiles Monophyletic?-Evidence for Subdivisions from Sequence and Morphological Data. Molecular phylogenetic and evolution, vol. 39: 16-32.

Meganathan, P. R., B. Dubey, and I. Haque. 2009. Molecular Identification of Crocodile Species Using Novel Primers for Forensic Analysis. Conserv Genet, vol. 10: 767-770. 
Meganathan, P. R., B. Dubey, M. A. Batzer, D. A. Ray, and I. Haque. 2010. Molecular Phylogenetic Analyses of Genus Crocodylus (Eusuchia, Crocodylia, Crocodylidae) and The Taxonomic Position of Crocodylus porosus. Molecular phylogenetic and evolution, vol. 57: 393-402.

Meredith, R.W., E.R. Hekala, G. Amato, and J. Gatesy. 2011. A Phylogenetic Hypothesis for Crocodylus (Crocodylia) based on Mitochondrial DNA: Evidence for a trans-Atlantic voyage from Africa to the New World. Molecular phylogenetic and evolution, vol. 60: 183-191.

Mount, D. W. 2004. Bioinformatics: Sequence and Genome Analysis. Cold Spring Harbor Laboratory Press. America. pp. 1-5.

Oaks, J. R. 2011. A Time-calibrated Species Tree of Crocodylia Reveals A Recent Radiation of The True Crocodiles. Evolution, vol. 65(11): 3285-3297.

Prusak, B., T. Grzybowski and J. Bednarek. 2005. Cytochrome b Gene (cytb) in Analysis of Anonymous Biological Traces and Its Application in Veterinary Diagnostics and Animal Conservation. Animal Sciences Paper and Reports, vol. 23(4): 229-236.

Uetz, P. and J. Hallermann. 2012. Tomistoma schlegelii (Muller, 1838). http://reptiledatabase.reptarium.cz/. on 28 August 2013.

Unanjak, S., P. Meesawat, K. Anyamaneeratch, D. Anuwareepong, K. Srikulnath, and K. Choowongkomon. 2011. Identification of Species (Meat and Blood Samples) Using Nested-PCR Analysis of Mitochondrial DNA. African Journal of Biotechnology, vol. 10(29): 5670-5676.

Vitt, L. J. and J. P. Caldwell. 2009. Herpetology: An Introduction Biology of Amphibians and Reptiles. Third Edition. Academic Press, Elsevier. Amsterdam. pp. 53-65, 505506.

Willis, R.E., L.R. McAliley, E.D. Neeley, L.D. Densmore III. 2007. Evidence for Placing The False Gharial (Tomistoma schlegelii) into The Family Gavialidae: Inferences from nuclear gene sequences. Molecular phylogenetic and evolution, vol. 43: 787-794. 